\title{
Nutritional potential of selected species of Arisaema Mart. from Nepal
}

\author{
LAXMI DHAKAL ${ }^{1, \bullet}$, BIVA ARYAL ${ }^{2,3}$, GIRI PRASAD JOSHI ${ }^{1}$, DEEPAK RAJ PANT ${ }^{1, \bullet \bullet}$ \\ ${ }^{1}$ Central Department of Botany, Tribhuvan University. 44613 Kirtipur, Nepal. \\ vemail: laxmidhakal704@gmail.com, v»deepak.pant@cdb.tu.edu.np; dr.pant@cdbtu.edu.np \\ ${ }^{2}$ Department of Botany, Amrit Campus, Tribhuvan University. 44600 Kathmandu, Nepal \\ ${ }^{3}$ Science Hub Nepal. Balaju-15, 44600 Kathmandu, Nepal
}

Manuscript received: 2 November 2020. Revision accepted: 21 November 2020.

\begin{abstract}
Dhakal L, Aryal B, Joshi GP, Pant DR. 2020. Nutritional potential of selected species of Arisaema Mart. from Nepal. Biodiversitas 21: 5703-5709. Species of Arisaema Mart. are believed to be poisonous, but few species are used as food in different communities. Therefore, an assessment of nutritional properties of six selected taxa of Arisaema including three edible taxa was made in order to find out their nutritional potential. Methanolic or aqueous extracts of samples (rhizomes and aerial parts) were analyzed for various nutritional and anti-nutritional parameters. On nutritional basis, the total starch content and total reducing sugar were found highest $(25.71 \pm 0.04 \mathrm{mg} / \mathrm{g}$ powder) and $(46.73 \pm 0.06 \mathrm{mg} / \mathrm{g}$ extract), respectively in aerial parts of A. echinatum. Total protein and phosphorus content was highest in rhizome of A. tortuosum var. curvatum. Similarly, extracts of aerial parts of A. tortuosum var. curvatum also possessed highest amount of total phenolic content $(52.67 \pm 0.24 \mathrm{mg} \mathrm{GAE} / \mathrm{g})$, total flavonoid content $(14.13 \pm 0.03 \mathrm{mg}$ $\mathrm{QE} / \mathrm{g})$, and also demonstrated best antioxidant activity $\left(\mathrm{IC}_{50}, 108.59 \pm 0.54 \mu \mathrm{g} / \mathrm{mL}\right)$ in terms of DPPH radical scavenging activity among the selected taxa. Inhibition of $\alpha$-amylase and $\alpha$-glucosidase in vitro was found to be highest (78.82 \%) in rhizome extracts of $A$. echinatum and extracts of aerial parts of A. concinnum (34.82\%), respectively.
\end{abstract}

Keywords: Antioxidant activity, anti-nutrients, Arisaema, nutritional value

\section{INTRODUCTION}

The global population at present is nearly 8 billion (Worldometers 2020) and is expected to reach 9-11 billion by 2050 (Roos et al. 2017). At the same time, the urban population will reach $70 \%$ as compared to $56 \%$ now (Worldometers 2020). There is a need to increase cereal production substantially to reach over 3 billion tons per year by 2050 (FAO 2009). These facts indicate a bleak future for the people living in the third world in terms of food security. It will be mostly the rural poor and marginalized populations who may have difficulty in having access to proper nutrition as they do not have resources to pay for their nutritional needs. In this context, use of wild edibles for human food or animal feed can be one of the approaches to address the problem of food security in these areas.

People in different parts of the World have been using wild edible plants to cater to their various needs. About 150 species representing nearly one-fifth of the number of wild species consumed as food in India, Malaysia, and Thailand have been identified as sources of emergency food crops (FAO 1992). Aryal et al. (2018) have reported about 99 species of wild edible non-cultivated plants from western Himalaya. These resources are available freely in nature and can help supplement the nutritional requirements of the local people as well as guarantee food security during difficult times.

Arisaema Mart. is one of the large and diverse genera of the flowering plant family Araceae. It comprises 151 species collected from Asia, Eastern Africa, and Eastern
North America (Li et al. 2010). It is represented by 16 species in Nepal (Rajbhandari and Rai 2017). There is perception among the general public in Nepal that all species of Arisaema are toxic. However, there are certain ethnic groups that are using different species of Arisaema as food. In upper Mustang, Nepal, A. jacquemontii is used as vegetables after processing (Lama et al. 2001). Similarly, Manandhar (2002) reported five different species of Arisaema including A. consanguineum, A. flavum, A. jacquemontii, A. tortuosum, and $A$. utile being used as food in Nepal. In addition, various species of Arisaema are also used in traditional medicine as anthelmintic (Balami 2004; Manandhar 2002), laxative (Bhattarai 1992), in skin infections (Gewali 2008; Manandhar 2002), etc.

Foodstuffs derived from plants including vegetables also contain different types of anti-nutritional factors which reduce nutrient availability in food used for human or animal consumption (Sahu et al. 2020). Plants of the family Araceae including Arisaema are rich in raphides (Keating 2004) which also act as toxin, affect calcium metabolism, and also form kidney stones (Petroski and Minich 2020). Similarly, anti-nutrients like amylase inhibitors that affect carbohydrate metabolism are reported to be present in food plants of Araceae like Colocasia (Kumari et al. 2012). In this background, present study aims to analyze nutritional potential and anti-nutrient (anti-amylase and antiglucosidase) activities of selected taxa of Arisaema from Nepal to find out differences, if any, in selected nutritional parameters among different taxa. The findings of the study will help to find out the possibility of using other taxa as well for human food and/or animal feed. 


\section{MATERIALS AND METHODS}

Collection and identification of plant samples

The list of taxa taken for study and their respective collection sites is presented in Table 1 and the photographs are presented in Figure 1. Samples (rhizomes and aerial parts) of Arisaema tortuosum var. curvatum were collected from Surkhet Valley (Western Nepal) while that of all other species were collected from different parts of Kathmandu valley, Nepal. Voucher specimens for Herbarium preparation were collected along with the samples and deposited at the National Herbarium, Kathmandu, Nepal (KATH), Nepal. Field notes along with GPS co-ordinates (Garmin eTrex-30) were also noted while collecting the samples.
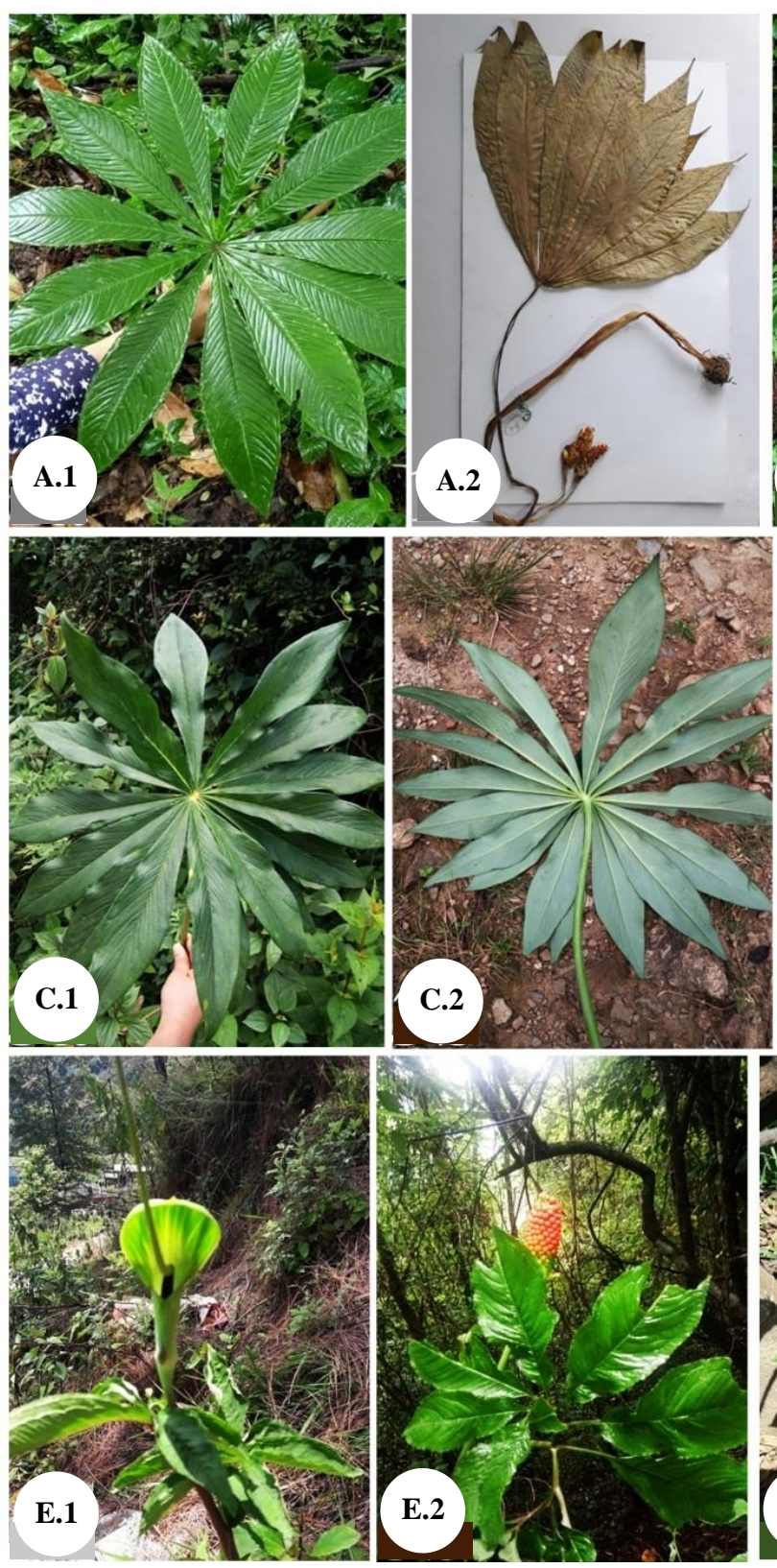
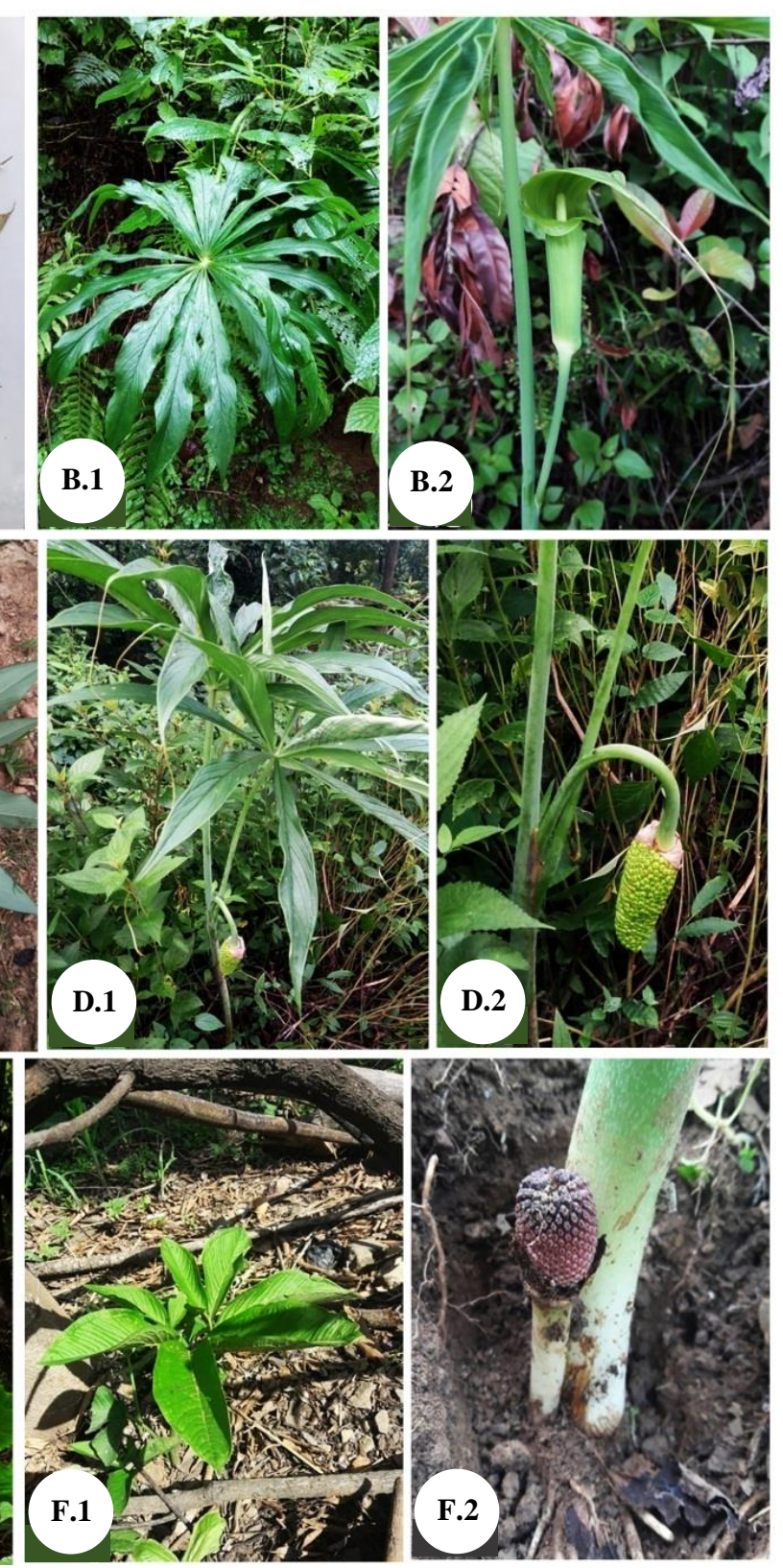

Figure 1. Photographs of selected species of Arisaema: A. A. concinnum, B. A. consanguineum, C. A. echinatum, D. A. erubescens, E. A. tortuosum var. tortuosum, F. A. tortuosum var. curvatum 


\section{Preparation of plant extracts}

The collected plants were chopped into small pieces and shade dried until constant weight. Dried samples were ground to fine powder separately by using mixer grinder. The powdered sample was mixed with 10 times the volume of solvent (Methanol or water) and subjected to sonication at $40 \mathrm{kHz}$ for 2 hours at $40-60^{\circ} \mathrm{C}$. Afterward, the mixture was filtered through Whatman No. 1 filter paper. The filtrate was collected and residue was mixed again with 10 times the volume of respective solvent. The mixture was subjected to sonication for one and half hours under similar conditions to ensure complete extraction. Both filtrates were mixed and concentrated under reduced pressure at $125 \mathrm{rpm}$ and $50^{\circ} \mathrm{C}$ in a rotary evaporator. The concentrated extracts were allowed to dry in heating Mantle at $50^{\circ} \mathrm{C}$. The dried extracts were scrapped off the Petri plates and stored in $2 \mathrm{~mL}$ polypropylene tubes at $-20^{\circ} \mathrm{C}$.

\section{Estimation of nutritional components \\ Reducing sugar}

Reducing sugar in aqueous extracts of rhizome and aerial parts of Arisaema species was determined by dinitro salicylic acid (DNS) method (Bailey 1988). Glucose was used as standard and reducing sugar was expressed as $\mathrm{mg}$ of glucose equivalent per gram dry weight of plant powder. In order to minimize the interference of other substances present in extracts of different species, negative controls were used for every sample and their absorbance readings deducted from that of samples from respective species.

\section{Total starch}

A half-gram $(0.5 \mathrm{~g})$ of plant powder was washed with $80 \% \quad(\mathrm{v} / \mathrm{v})$ hot ethanol (Changshu Hongseng Fine Chemicals, Changshu, China) twice to remove sugar, and residue was collected. Then excess ethanol was dried off by evaporation in hot air oven. After complete drying $5 \mathrm{~mL}$ of distilled water and $6.5 \mathrm{~mL}$ of perchloric acid (Qualigens chemicals, Mumbai, India) was added to the residue and mixed well. Then the samples were left to stand at $4^{\circ} \mathrm{C}$ for $20 \mathrm{~min}$. Afterward supernatant was filtered twice for further tests by DNS method to calculate the amount of sugar as glucose equivalent. Starch content was obtained by multiplying the glucose content by a factor of 0.9 following the method described by Chow and Landhausser (2004).

\section{Total protein}

Total protein content of the aqueous extract of plant samples was quantified as per Bradford assay (He 2011).

\section{Total phosphorus}

The powdered plant sample $(0.5 \mathrm{~g})$ was burnt to ash in a muffle furnace at $550^{\circ} \mathrm{C}$. Total phosphorus content present in the ash was determined following the method of Bertramson (1942).

\section{Total phenolic and flavonoid contents}

Total phenolic and flavonoid content were determined only from methanolic extracts. Total phenolic content (TPC) was determined using Folin-Ciocalteu Method (Ainsworth and Gillespie 2007) and total flavonoid content
(TFC) was determined using the Aluminum Chloride $\left(\mathrm{AlCl}_{3}\right)$ colorimetric method (Roy et al. 2011).

\section{Antioxidant activity}

The free radical scavenging activity of samples and standard ascorbic acid solution in methanol was determined based on their ability to react with stable methanolic solution $(0.2 \mathrm{mM})$ of DPPH (Fisher Scientific India Limited) in dark (Singh et al. 2002). The absorbance (abs.) of the solution was measured at $517 \mathrm{~nm}$ using UV-Visible Spectrophotometer (CT8600, E-chrome Tech, Taiwan). The percentage of free radical scavenging activity (RSA) of the plant sample was calculated by using the following formula:

$\%$ Radical Scavenging activity $(\mathrm{RSA})=100 *$ (control abs. - sample abs.)/control abs.

A curve was obtained by plotting the percentage RSA against concentration. Based on the standard curve, $\mathrm{IC}_{50}$ was calculated by using linear equation of the curve obtained.

$$
\begin{aligned}
& \mathrm{Y}=\mathrm{a}^{*} \mathrm{X}+\mathrm{b} \\
& \mathrm{IC}_{50}=(50-\mathrm{b}) / \mathrm{a}
\end{aligned}
$$

Where, $\mathrm{X}=$ Concentration, $\mathrm{Y}=\% \mathrm{RSA}, \mathrm{a}$ and $\mathrm{b}$ are the coefficient and constant, respectively, of the linear equation.

\section{Evaluation of anti-amylase and anti-glucosidase activity}

Anti-amylase and anti-glucosidase activity of the methanolic plant extracts in vitro was measured using inhibition assays for the enzymes porcine pancreatic amylase and $\alpha$-glucosidase (Sigma Aldrich, Germany) using protocols described by Ahmed et al. (2009) and Si et al. (2010).

\section{Data analysis}

All the data are presented as mean $\pm \mathrm{SD}$ of three samples. The data were statistically analyzed by using Microsoft Excel 2010.

\section{RESULTS AND DISCUSSION}

\section{Nutritional components}

Nutritional value of different species of Arisaema is presented in Table 2. The highest amount of total reducing sugar $(46.73 \pm 0.06 \mathrm{mg} / \mathrm{g}$ extract) was found in aerial parts of A. echinatum and the lowest $(18.30 \pm 0.46 \mathrm{mg} / \mathrm{g}$ extract) was in rhizome of $A$. concinnum. The highest starch content $(25.71 \pm 0.04 \mathrm{mg} / \mathrm{g}$ powder$)$ was found in aerial parts of A. echinatum and the lowest $(18.13 \pm 0.04 \mathrm{mg} / \mathrm{g}$ powder $)$ was in aerial parts of A. tortuosum var. tortuosum. The total protein content ranged from $0.90 \pm 0.16 \mathrm{mg} \mathrm{BSA} / \mathrm{g}$ in rhizome of A. tortuosum var. tortuosum to $30.78 \pm 0.37 \mathrm{mg}$ $\mathrm{BSA} / \mathrm{g}$ in A. tortuosum var. curvatum. The highest phosphorous content $(176.48 \pm 3.36 \mu \mathrm{g} / \mathrm{g})$ was found in rhizome of A. tortuosum var. curvatum and the lowest $(16.48 \pm 1.68 \mu \mathrm{g} / \mathrm{g})$ was in rhizome of $A$. consanguineum. 
Table 2. Nutritional value of different species of Arisaema. The highest and lowest values in each parameter are underlined.

\begin{tabular}{lcccc}
\hline Extract & $\begin{array}{c}\text { Total starch content } \\
(\mathbf{m g} / \mathbf{g} \text { powder})\end{array}$ & $\begin{array}{c}\text { Total reducing sugar } \\
(\mathbf{m g} / \mathbf{g} \text { extract })\end{array}$ & $\begin{array}{c}\text { Total protein } \\
\text { content }(\mathbf{m g B S A} / \mathbf{g})\end{array}$ & $\begin{array}{c}\text { Total phosphorous } \\
\text { content }(\boldsymbol{\mu g} / \mathbf{g})\end{array}$ \\
\hline ACC-A & $25.39 \pm 0.06$ & $42.07 \pm 0.35$ & $3.00 \pm 0.05$ & $19.39 \pm 5.55$ \\
ACC-R & $21.69 \pm 0.07$ & $18.30 \pm 0.46$ & $12.77 \pm 0.07$ & $114.72 \pm 5.60$ \\
ACG-A & $21.86 \pm 0.07$ & $30.13 \pm 0.32$ & $8.98 \pm 0.04$ & $38.79 \pm 4.20$ \\
ACG-R & $19.80 \pm 0.07$ & $29.60 \pm 0.10$ & $11.30 \pm 0.11$ & $16.48 \pm 1.68$ \\
AEC-A & $25.71 \pm 0.04$ & $46.73 \pm 0.06$ & $1.10 \pm 0.18$ & $41.21 \pm 4.20$ \\
AEC-R & $19.36 \pm 0.07$ & $31.20 \pm 0.60$ & $3.33 \pm 0.14$ & $65.94 \pm 4.44$ \\
AER-A & $24.62 \pm 0.04$ & $44.67 \pm 0.31$ & $23.40 \pm 1.29$ & $43.64 \pm 7.27$ \\
AER-R & $18.93 \pm 0.05$ & $26.63 \pm 0.47$ & $25.58 \pm 0.09$ & $28.12 \pm 4.44$ \\
ATC-A & $18.63 \pm 0.05$ & $39.43 \pm 0.45$ & $8.98 \pm 0.15$ & $99.39 \pm 4.20$ \\
ATC-R & $19.15 \pm 0.08$ & $33.63 \pm 0.38$ & $30.78 \pm 0.37$ & $176.48 \pm 3.36$ \\
ATT-A & $18.13 \pm 0.04$ & $20.93 \pm 0.47$ & $12.07 \pm 0.23$ & $80.00 \pm 7.27$ \\
ATT-R & $19.56 \pm 0.08$ & $28.30 \pm 0.26$ & $0.90 \pm 0.16$ & $89.21 \pm 6.06$ \\
\hline Note: ACC: $A$.
\end{tabular}

Note: ACC: A. concinnum, ACG: A. consanguineum, AEC: A. echinatum, AER: A. erubescens, ATC: A. tortuosum var. curvatum, ATT: A. tortuosum var. tortuosum. The letter separated by hyphen- represents the parts used: aerial parts (A) or rhizome (R)

\section{Total phenolic and total flavonoid content}

Total phenolic content (mg gallic acid equivalent per gram) in methanolic extracts were found to be higher in aerial parts than that in rhizomes in all the taxa except $A$. concinnum (Figure 2). The highest TPC content (52.67 $\pm 0.24 \mathrm{mg} \mathrm{GAE} / \mathrm{g})$ was found in aerial parts of $A$. tortuosum var. curvatum while the lowest TPC content $(8.02 \pm 0.3 \mathrm{mg} \mathrm{GAE} / \mathrm{g})$ was found in aerial parts of $A$. concinnum (Figure 3$)$. The highest amount of TFC (14.13 \pm $0.03 \mathrm{mgQE} / \mathrm{g}$ extract) was found in aerial parts of $A$. tortuosum var. curvatum and lowest $(2.82 \pm 0.03 \mathrm{mg} \mathrm{QE} / \mathrm{g}$ extract) in rhizome of A. tortuosum var. tortuosum. The values of other species were between these extremes.

\section{Antioxidant activity}

The antioxidant activities of crude extracts of different species of Arisaema expressed in terms $\mathrm{IC}_{50}$ value of DPPH radical scavenging activity is shown in Figure 4. The minimum $\mathrm{IC}_{50}$ value was reported in A. tortuosum var. curvatum $(108.59 \pm 0.54 \mu \mathrm{g} / \mathrm{mL})$ and the maximum $\mathrm{IC}_{50}$ value was reported in $A$. concinnum $(820.59 \pm 2.59 \mu \mathrm{g} / \mathrm{mL})$. The extract with lowest $\mathrm{IC}_{50}$ value i.e., $A$. tortuosum var. curvatum was found to show highest antioxidant activity.

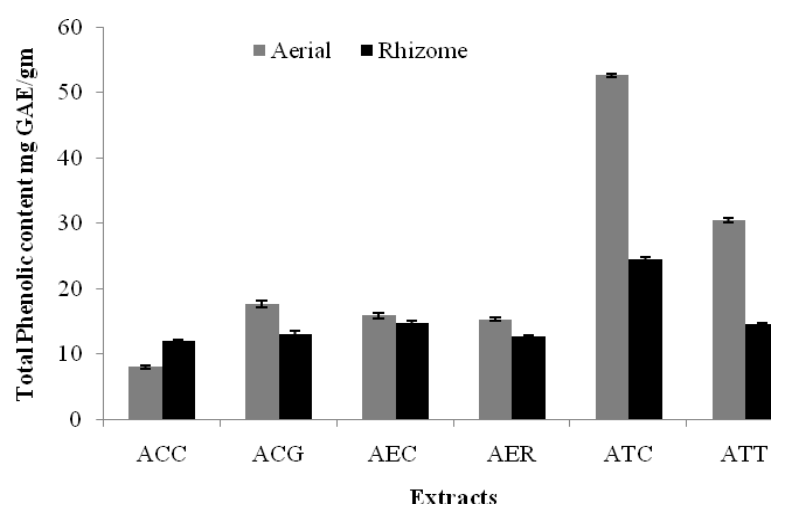

Figure 2. Total phenolic content present in methanolic extract of different taxa of Arisaema. Note: ACC: A. concinnum, ACG: A. consanguineum, AEC: A. echinatum, AER: A. erubescens, ATC: A. tortuosum var. curvatum, ATT: A. tortuosum var. tortuosum

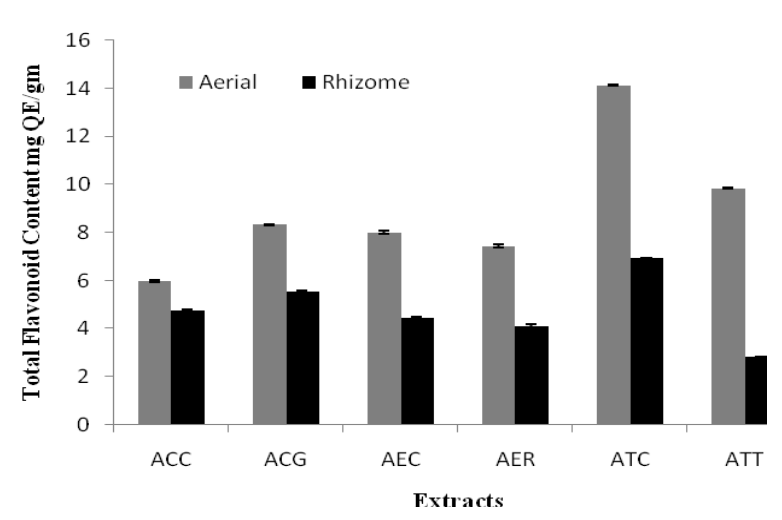

Figure 3. Total flavonoid content present in methanolic extract of different taxa of Arisaema. Note: ACC: A. concinnum, ACG: A. consanguineum, AEC: A. echinatum, AER: A. erubescens, ATC: A. tortuosum var. curvatum, ATT: A. tortuosum var. tortuosum

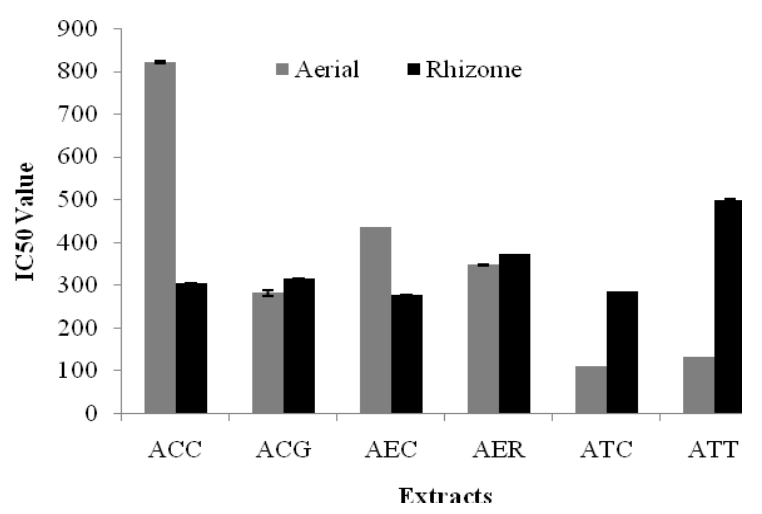

Figure 4. $\mathrm{IC}_{50}$ value $(\mu \mathrm{g} / \mathrm{mL})$ of $\mathrm{DPPH}$ radical scavenging activity in extracts of selected species of Arisaema. Note: ACC: A. concinnum, ACG: A. consanguineum, AEC: A. echinatum, AER: A. erubescens, ATC: A. tortuosum var. curvatum, ATT: A. tortuosum var. tortuosum 


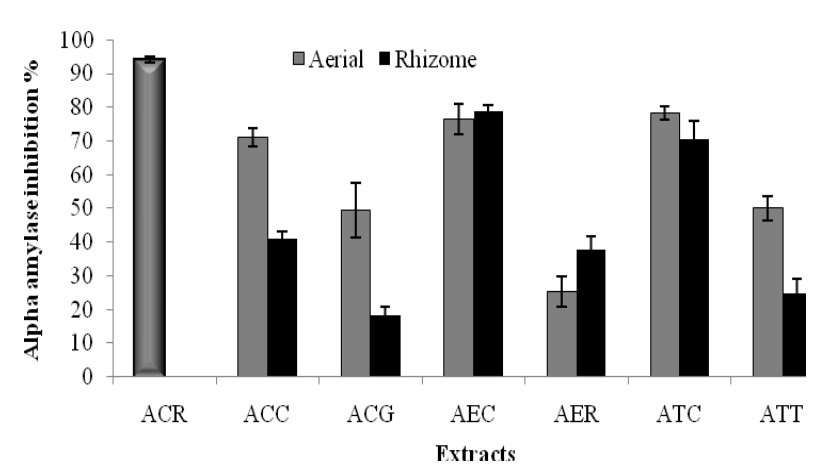

Figure 5. Inhibition of $\alpha$-amylase by methanolic extract of selected species of Arisaema. Note: ACC: A. concinnum, ACG: A. consanguineum, AEC: A. echinatum, AER: A. erubescens, ATC: A. tortuosum var. curvatum, ATT: A. tortuosum var. tortuosum

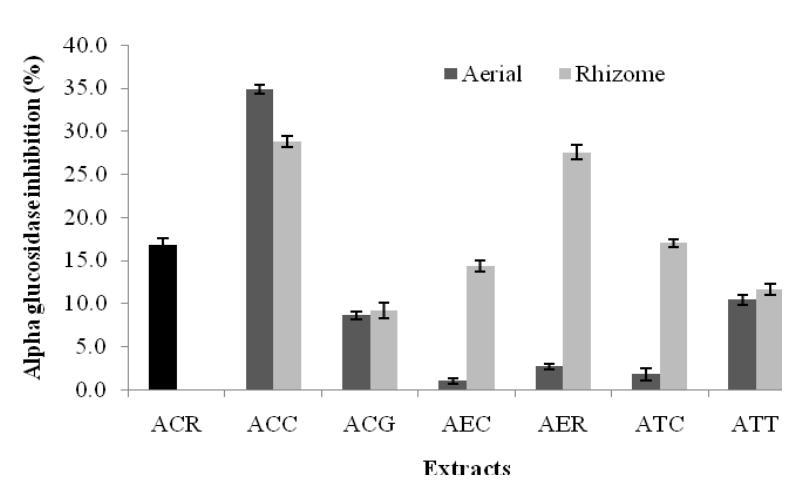

Figure 6. Inhibition of $\alpha$-glucosidase by methanolic extract of selected species of Arisaema. Note: ACC: A. concinnum, ACG: A. consanguineum, AEC: A. echinatum, AER: A. erubescens, ATC: A. tortuosum var. curvatum, ATT: A. tortuosum var. tortuosum

\section{Anti-amylase and anti-glucosidase activity}

The anti-amylase and anti-glucosidase activities of methanolic extracts of different species of Arisaema are shown in Figures 5 and 6 . Inhibition of $\alpha$-amylase in vitro was found to be highest (78.82\%) in rhizome extracts of $A$. echinatum while that of $\alpha$-glucosidase was highest (34.82 $\%)$ in extracts from aerial parts of A. concinnum. At the same concentration, Acarbose showed $94.12 \%$ of inhibition in $\alpha$-amylase and $16.79 \%$ of inhibition in $\alpha$ glucosidase, respectively.

\section{Discussion}

The Diplazium esculentum is a wild edible vegetable with having reducing sugar content of $21.5 \mathrm{mg} / \mathrm{g}$ (Archana et al. 2013), which is comparable with that of aerial parts of A. tortuosum. Similarly, some leafy vegetables like mint, coriander, curry leaves have a reducing sugar range of 35\% (Vyankatrao 2015). The reducing sugar in aqueous extracts of different species of Arisaema lied between that of Archana et al. (2013) and Vyankatrao (2015).

Total carbohydrate content as high as $26.8 \%$ on a fresh weight basis has been reported in rhizomes of Colocasia esculenta (Temesgen and Retta 2015). However, the carbohydrate content (starch equivalent) in rhizome of Arisaema is much lower. Since the starch content in plant tissues varies with species, parts used, and maturity, some of these factors might have contributed to lower carbohydrate content in present investigation.

The crude protein in Colocasia esculenta was 307 $\mathrm{gm} / \mathrm{kg} \mathrm{dw}$ (Ejoh et al. 1996). The total protein content in A. tortuosum var. curvatum is higher than other species used in present study but much lower than that of Colocasia esculenta. The lower protein content in comparison to $C$. esculenta may be attributed to the fact that wild plants grow under nutrient stressed conditions compared to cultivated ones.

The phosphorus content in common edible plants varies from 32 to $138 \mathrm{mg} / 100 \mathrm{~g}$ (Jaarsveld et al. 2014). The total phosphorus content in rhizomes and aerial parts of different species of Arisaema in present investigation was found to be much lower than that reported for $C$. esculenta. Since

the nutritional value varies with cultivated and wild plants, cultivated plants get additive nutrition which may responsible for having more carbohydrates, protein, and phosphorous content than wild plants. Meanwhile, the starch content, protein content, and phosphorous content in plant tissues varies with species, parts used, nutritional status of the plants, etc., some of these factors might have contributed to low nutrient contents in present investigation.

Phenolic compounds are a large class of plant secondary metabolites having structure range from simple (phenolic acids) to diverse (polyphenols) forms. Phenolic compounds are important for the quality of plant-based food. These compounds also contribute to health benefits associated with dietary consumption of fruits and vegetables (Cheynier 2012). Baba and Malik (2015) reported that methanolic extracts from the rhizome of $A$. jacquemontii had phenolic content $45.17 \pm 1.70 \mathrm{mg} \mathrm{GAE} / \mathrm{g}$. Similarly, Nile and Park (2013) reported that the TPC value of $86.2 \mathrm{mg}$ catechin equivalent/g in extracts from rhizomes of A. tortuosum. The value of TPC in methanolic extracts of rhizomes of all taxa of Ariesaema in present study is much lower than that reported by Baba and Malik (2015). However, the highest amount of TPC in A. tortuosum var. curvatum among the studied taxa reaffirms its selection as one of the edible species by the hills tribe in Surkhet valley (Karnali), Nepal.

Similarly, flavonoids are diverse group of phytochemicals found in almost all fruits and plants parts. Along with carotenoids, they are responsible for the vivid colors in fruits and vegetables. Flavonoids also have powerful antioxidants, anti-inflammatory and immune system benefits. They are also used in prevention of neurodegenerative diseases (Spagnulo et al. 2017). Baba and Malik (2015) reported that the TFC value of $35 \pm 2.20$ $\mathrm{mg}$ rutin equivalent/g in tuber extracts of $A$. jacquemontii while Nile and Park (2013) reported TFC value of 175.5 $\mathrm{mg}$ rutin equivalent/g in A. tortuosum tuber extract. Since the flavonoid content in present study is expressed in quercetin equivalents, direct comparison with earlier reports is not possible. Similar to TPC, the TFC was also 
found to be higher in aerial parts than in rhizomes. This may be attributed to high synthetic activities in aerial parts due to the presence of chloroplast, photosynthetic activity and Reactive oxygen species (ROS).

Antioxidants are compounds that prevent oxidation and prolong the life of oxidizable matters. Extracts of different species of Arisaema also possess different antioxidant compounds similar to other plants. Though, the overall trend of antioxidant activity of extracts of Arisaema in methanol extract are similar to those reported earlier, the values are quite different. Previously, methanolic extract of rhizomes of $A$. tortuosum was reported to have higher $(852 \pm 1.3 \mu \mathrm{g} / \mathrm{mL}) \mathrm{IC}_{50}$ value (Nile and Park 2013). In present study, the highest $\mathrm{IC}_{50}(820.59 \pm 2.59 \mu \mathrm{g} / \mathrm{mL})$ was found in methanolic extract of aerial parts of $A$. concinnum and lowest $(108.59 \pm 0.54 \mu \mathrm{g} / \mathrm{mL})$ in aerial parts of $A$. tortuosum var. curvatum. The $\mathrm{IC}_{50}$ value of methanolic extracts of rhizomes for both varieties of A. tortuosum is much less than that reported by Nile and Park (2013).

The present study revealed that the species which have been used as vegetable had higher antioxidant potential than the rest of other species. Similarly, the extracts of aerial parts were found to possess higher percentages of Radical Scavenging Activity than that of underground parts. This is because chloroplast and mitochondria are two main powerhouses and sites of ROS generator units in plant cells. These parts are also involved in maintaining the fine balance between energy-linked function and control of ROS production (Kasote et al. 2015).

Pancreatic amylases and glucosidase are the enzymes that help to digest complex carbohydrates present in foodstuff into simple, soluble forms like glucose. Inhibitors of these enzymes present in food can be used as hypoglycemic or antihyperglycemic agents for the management of diabetes mellitus. Since some amylase inhibitors are heat resistant and do not get degraded while cooking (Temesgen and Retta 2015), presence of such inhibitors in foodstuff contributes to anti-nutritional properties. The presence of very weak anti-glucosidase activity in extracts of aerial parts of most of the species indicates possibility of using them all as food. On the contrary, high anti-amylase activity in extracts of aerial parts does not support it. However, continuous use of species like A. concinnum, A. consanguineum, and $A$. tortuosum var. curvatum as vegetables by people in different parts of Nepal indicates that the amylase inhibitors present in these plants are probably unstable compounds that get degraded during processing and/or cooking such that the people do not have any problems associated with digestion after their consumption.

A comparison of various nutritional and anti-nutritional properties among selected taxa of Arisaema Mart. revealed differences in values of different parameters including total phenolic and flavonoids content, and antioxidant potential among the tested species. In terms of nutritional value, the highest amount of carbohydrates content was found in aerial parts of $A$. echinatum. The highest amount of protein and total phosphorus was found in rhizome of A. tortuosum var. curvatum. In terms of TPC, TFC, and antioxidant activity, aerial part of A. tortuosum var. curvatum was found to be the best among the tested species. All the tested species showed moderate inhibitory activity against $\alpha$ amylase and weak activity against $\alpha$-glucosidase. These findings highlight the nutritional potential of different species of Arisaema and show the possibility of using the remaining species as food supplements/vegetables or animal feed, however, further studies on allergenicity and toxicity are needed in order to conclude them as being safe for general consumption.

\section{ACKNOWLEDGEMENTS}

A special thanks go to University Grants Commission (UGC) Nepal for financial support for LD in research work. The support of Central Department of Biotechnology, Central Department of Environmental Science, Tribhuvan University, Nepal for providing the laboratory facilities and National Herbarium, Nepal (KATH) for access to herbarium of Arisaema is highly acknowledged. The authors are also grateful to the Department of Plant Resources, Thapathali for granting permission to collect plant samples from the wild.

\section{REFERENCES}

Ahmed F, Chandra JNNS, Timmaiah NV. 2009. An in vitro study on inhibitory activities of Eugenia jambolana seeds against carbohydrate hydrolyzing enzymes. J Young Pharmacists 1: 317-321. DOI: 10.4103/0975-1483.59320.

Ainsworth EA, Gillespie KM. 2007. Estimation of total phenolic content and other oxidation substrates in plant tissues using Folin-Ciocalteu reagent. Nature Protocols 2: 875-877. DOI: 10.1038/nprot.2007.102.

Archana GN, Pradesh S, Devi C, Mini I, Swapna, TS. 2013. Diplazium esculentum: A wild nutrient-rich leafy vegetables from westerns Ghats. In: Sabu A, Augustine A (eds.) Prospects in bioscience: Addressing the Issues. Springer, India.

Aryal KP, Poudel S, Chaudhary RP, Chettri N, Chaudhary P, Ning W, Kotru R. 2018. Diversity and use of wild edible non-cultivated edible plants in the Western Himalaya. J Ethnobiol Ethnomed 14: 10. DOI: 10.1186/s13002-018-0211-1.

Baba SA, Malik SA. 2015. Determination of total phenolic and flavonoids content, antimicrobial and antioxidant activity of root extract of Arisaema jacquemontii Blume. J Taibah Univ Sci 9 (4): 449-454. DOI: 10.1016/j.jtusci.2014.11.001.

Bailey MJ. 1988. A note on the use of dinitrosalilclylic acid for determining the products of enzymatic reactions. Appl Microbiol Biotechnol 29: 494-496. DOI: 10.1007/BF00269074.

Balami NP. 2004. Ethnomedicinal uses of plants among the Newar community of Pharping village of Kathmandu district, Nepal. Tribhuvan Univ J 24 (1): 13-19. DOI: 10.3126/tuj.v24i1.251.

Bertramson BR. 1942. Phosphorous analysis of plant material. Plant Physiol 17 (3): 447-454.

Bhattarai NK. 1992. Medical ethnobotany in the Karnali zone, Nepal. Econ Bot 46 (3): 257-261

Cheynier V. 2012. Phenolic compounds: From plants to food. Phytochem Rev 11 (1-2): 153-177. DOI: 10.1007/s11101-012-9242-8.

Chow PS, Landhausser SM. 2004. A method for routine measurements of total sugar and starch content in woody plant tissues. Tree Physiol 24: 1129-1136. DOI: 10.1093/treephys/24.10.1129.

Ejoh AR, Mbiapo FT, Fokou E. 1996. Nutrient composition of the leaves and flowers of Colocasia esculenta and the fruits of Solanum melongena. Plant Foods Human Nutr 49: 107-112. DOI: 10.1007/bf01091966.

FAO. 1992. Forests, trees and food. Food and Agriculture Organization, Rome.

FAO. 2009. How to feed the world in 2050. FAO, Rome. 
Gewali MB. 2008. Aspects of traditional medicine in Nepal. Institute of Natural Medicine, University of Tayoma, Japan.

He F. 2011. Bradford protein assay. Bio-Protocol 101: e45.DOI: 10.21769/BioProtoc. 45 .

Jaarsveld VP, Faber M, Heerden VI, Wenhold F, Rensburg JW, Averbeke VW. 2014. Nutrient content of eight African leafy vegetables and their potential contribution of dietary reference intakes. J Food Compos Anal 33: 77-84. DOI: 10.1016/j.jfca.2013.11.003.

Kasote DM, Katyare SS, Hegde MV, Bae H. 2015. Significance of antioxidant potential of plants and its relevance to therapeutic applications. Intl J Biol Sci 11 (8): 982-991. DOI: 10.7150/ijbs. 12096.

Keating R. 2004. Systematic occurrence of raphide crystals in Araceae. Ann Mo Bot Gard 91 (3): 495-504.

Kumari B, Sharma P, Nath AK. 2012. A-amylase inhibitors from local Himalayan collections of Colocasia: Isolation, purification, characterization and selectivity towards $\alpha$ - amylase from various sources. Pestic Biochem Physiol 103 (1): 49-55. DOI: 10.1016/j.pestbp.2012.03.003.

Lama YC, Ghimire SK, Thomas YA. 2001. Medicinal Plants of Dolpo: Amchi's Knowledge and Conservation. WWF Nepal Program, Kathmandu.

Li H, Zhu G, Murata J. 2010. Arisaema. Flora of China 23: 43-69.

Manandhar NP. 2002. Plants and People of Nepal. Timber Press, Oregon.

Nile SH, Park WS. 2013. HPTLC analysis, antioxidant, anti-Inflammatory and antiproliferative activities of Arisaema tortuosum tuber extract. Pharmaceut Biol 52: 221-227. DOI: 10.3109/13880209.2013.831110.

Petroski W, Minich DM. 2020. Is there such thing as "anti-nutrients"? A narrative review of perceived problematic plant compounds. Nutrients 12: 2929. DOI: $10.3390 /$ nu12102929.

Rajbhandari KR, Rai SK. 2017. Handbook of the Flowering Plants of Nepal. Department of Plant Resources. Government of Nepal, Kathmandu.
Roos E, Bajzelj B, Smith P, Patel M, Little D, Garnett T. 2017. Greedy or needy? Land use and climate impacts of food in 2050 under different livestock futures. Global Environ $\mathrm{Ch}$ 47: 1-12. DOI: 10.1016/j.gloenvcha.2017.09.001.

Roy N, Laskar RA, Sk I, Kumari D, Ghosh T, Begum NA. 2011. A detailed study on the antioxidant activity of the stem bark of Dalbergia sissoo Roxb., an Indian medicinal plant. Food Chem 126 (3): 1115-1121. DOI: 10.1016/j.foodchem.2010.11.143.

Sahu P, Tripathy B, Raut S. 2020. Significance of anti-nutritional compounds in vegetables. In: Pawar NB (ed.) Agriculture and Rural Development: Spatial issues, challenges and approaches. Jyotikiran Publication, Pune.

Si MM, Lou JS, Zhu CX, Shen JN, Wu HH, Yang B, H QJ, Wu HS. 2010. Insulin-releasing and $\alpha$-glucosidase inhibitory activity of ethyl acetate fraction of Acorus calamus in vitro and in vivo. J Ethnopharmacol 128: 154-159. DOI: 10.1016/j.jep.2009.12.044.

Singh RP, Murthy KNC, Jayaprakasha GK. 2002. Studies on the antioxidant activity of pomegranate (Punica granatum) peel and seed extracts using in vitro models. J Agric Food Chem 50 (1): 81-86. DOI: $10.1021 / \mathrm{jf0} 10865 \mathrm{~b}$.

Spagnuolo C, Moccia S, Russo GL. 2017. Anti-inflammatory effects of flavonoids in neurodegenerative disorders. Eur J Med Chem 153: 105-115. DOI: 10.1016/j.ejmech.2017.09.001.

Temesgen M, Retta N. 2015. Nutritional potential, health and food security benefits of Taro Colocasia esculenta L.: A review. Food Sci Quality Manag 36: 23-30.

Vyankatrao NP. 2015. Effect of drying method on nutritional value of some vegetables. Biosci Discov 6 (1-I): 72-99.

Worldometers. 2020. https://www.worldometers.info/worldpopulation/world-population-by-year [19 August 2020]. 